\title{
Hidden husbandry: disentangling a disturbed profile at Beckery Chapel, a medieval ecclesiastical site near Glastonbury (UK)
}

Article

Accepted Version

Banerjea, R. Y., Morandi, L. F., Williams, K. and Brunning, R. (2021) Hidden husbandry: disentangling a disturbed profile at Beckery Chapel, a medieval ecclesiastical site near Glastonbury (UK). Environmental Archaeology: The Journal of Human Palaeoecology, 26 (4). pp. 367-387. ISSN 1461-4103 doi: https://doi.org/10.1080/14614103.2020.1768333 Available at https://centaur.reading.ac.uk/92572/

It is advisable to refer to the publisher's version if you intend to cite from the work. See Guidance on citing.

To link to this article DOI: http://dx.doi.org/10.1080/14614103.2020.1768333

Publisher: Taylor \& Francis

All outputs in CentAUR are protected by Intellectual Property Rights law, including copyright law. Copyright and IPR is retained by the creators or other copyright holders. Terms and conditions for use of this material are defined in the End User Agreement. 


\section{www.reading.ac.uk/centaur}

\section{CentAUR}

Central Archive at the University of Reading

Reading's research outputs online 


\title{
Hidden husbandry: disentangling a disturbed profile at Beckery Chapel, a medieval ecclesiastical site near Glastonbury (UK)
}

\author{
Rowena Y. Banerjea ${ }^{1,2}$, Lionello F. Morandi ${ }^{1,3}$, Kevin Williams ${ }^{1}$, Richard Brunning ${ }^{4}$ \\ ${ }^{1}$ Quaternary Scientific, School of Archaeology, Geography, and Environmental Science, University of \\ Reading, UK, RG6 6AB \\ ${ }^{2}$ Department of Archaeology, School of Archaeology, Geography, and Environmental Science, \\ University of Reading, UK, RG6 6AB \\ ${ }^{3}$ Institut für Naturwissenschaftliche Archäologie, University of Tübingen, Rümelinstraße 23, 72074 \\ Tübingen, Germany \\ ${ }^{4}$ South West Heritage Trust, Somerset Heritage Centre, Brunel Way, Norton Fitzwarren, Somerset, \\ TA2 6SF, UK
}

Corresponding author's e-mail: $\underline{\text { r.y.banerjea@reading.ac.uk }}$

\section{Keywords}

Soil micromorphology; palaeoparasitology; phytoliths; geoarchaeology; coprophilous fungi; bioturbation

\begin{abstract}
Beckery Chapel, near Glastonbury, is the site which has the earliest scientific dating evidence for monastic life in the UK, and later in the medieval period became a Chapel that played a significant role as a destination for pilgrims, as part of the Glastonbury Abbey estate. The site was previously excavated in the 1880s and the 1960s, and in 2016 the South West Heritage Trust excavated a building, that proved to be an outbuilding used when the medieval chapel was in operation. Soil micromorphological analysis was conducted first to understand the sediments within the profile from this building, which appeared fairly homogenous and bioturbated in the field. It untangled the bioturbation processes and revealed a rare northern European, geoarchaeological example of a livestock enclosure from a dryland context in this temperate environment. The results of our innovative multi-proxy approach highlight the potential and methodological considerations for future studies to integrate micromorphology, palaeoparasitology and mycology to examine animal management on dryland archaeological sites. They increase the knowledge of the economic activities of the ecclesiastical occupation at Beckery, contributing to an enhanced understanding of the Chapel site, its wider landscape and its role as part of the Glastonbury Abbey estate.
\end{abstract}




\section{Introduction}

What archaeological potential does a highly disturbed profile have? This research explores the extent to which it is possible to identify and reconstruct activity events from a bioturbated profile, working with the assertion that even in badly degraded archaeological deposits it can still be possible to make significant inferences about their interpretation (Schiffer 1983). In this context, the research examines how the integration of soil micromorphology and extracted microfossils can reconstruct the nuances in animal husbandry in relation to the activities at Beckery Chapel near Glastonbury, Somerset. Beckery has the earliest radiometric dating for monastic life in the UK, suggesting that monastic life began in the 5 th or early 6 th century AD. This date shows that a monastery was in place at Beckery before Somerset was conquered by the Saxon kings of Wessex in the mid 7th Century, after which the monastic function was transferred to a new nearby Abbey at Glastonbury. Beckery remained part of the Abbey estate and a Chapel was built on the site, which became a significant place of pilgrimage associated with the legends of St. Brigit and King Arthur (Gilchrist 2020: 157-166; Gilchrist and Green 2015: 394).

One of the 'cornerstones of medieval archaeology' seeks to understand religious change between the collapse of the Roman Empire and the Reformation, but this area of research has been riven by period, denominational, and geographical divisions (Thomas et al. 2017). Beckery plays a pivotal role in understanding the Christianisation process in the British Isles and the medieval pilgrim economy. Consequently, a detailed knowledge of the site will contribute to an important this wider area of discussion in medieval archaeology.

Beckery is situated on a small island of solid geology in the floodplain $2 \mathrm{~km}$ to the south-west of Glastonbury (Fig. 1). Activity at the site began in the Iron Age continuing into the later medieval period when a sequence of stone chapels was built over the monastic cemetery. The first excavations were by John Morland in 1887 and 1888, exposing burials, a chapel, and a building interpreted as a priest's house (Morland 1989; Bulleid 1936). The chapel and part of the priest's house were re-excavated by Philip Rahtz in 1967-1968 (Rahtz and Hirst 1974). In 2016 the South West Heritage Trust excavated a further building, identified through geophysical survey, which is the subject of this paper. Deep deposits had built up inside the building over several centuries during the medieval period, contemporary with the chapel, but no credible floor surface was observed during excavation. There was a deep accumulation of material within this building comprising ceramics, building materials and faunal remains (see Higbee 2017). The purpose of this material or the function of the building was not clear during excavation, but the large size of some of the pottery fragments suggested that the material culture probably did not represent the primary use of the building. The sediments had been reworked and were sealed by a layer of broken roofing stone, which is presumed to represent the collapse or demolition of the structure after the dissolution of the monasteries.

The term bioturbation describes the disturbance or reworking of soils and sediments by biological agents such as plants, macro-, meso-, and micro-fauna. The first research on the topic was conducted by Darwin (1881), when he observed the influence of earthworms on soil formation in his garden, and the term itself coined by Richter (1952). Bioturbation can pose problems for interpreting the formation processes of archaeological stratigraphy, artefact and ecofact assemblages, but the 
presence of extensive bioturbation (such as that arising from the colonisation of an area by plants or insect activity in decaying vegetation) can also reflect microenvironmental conditions created by human activities, such as dumping refuse in a specific location outside a building (Schiffer 1983). The effects of bioturbation have been researched on urban sites, as a significant contributory factor for the formation of 'Dark Earth' (eg. Borderie et al. 2014; Macphail 1994), and on cave sites (Stiner et al. 2001). They have been examined using experimental archaeology (Banerjea et al. 2015), and through the study of the effects of earthworm (Canti 2003) and termite (Grave and Kealhofer 1999) activity on archaeological sites. The application of soil micromorphology in experimental archaeology research showed that the burrowing activity of ants created an entirly new layer below an existing layer (Banerjea et al. 2015).

However, the effects of bioturbation processes on the reworking of environmental assemblages still remains an under-researched issue, and their identification during excavation can still sometimes lead to the presumption that a site or area has very limited potential due to the disturbance (Schiffer 1983; Canti 2003). A growing body of soil micromorphological research is bolstering our understanding of the effects of bioturbation processes such as faunal activity (Kooistra and Pulleman 2018; Canti 2017) on our interpretations of palaeoenvironmental remains to provide more robust interpretations of the data and to exploit their full potential. Several studies advocate the application of micromorphology to understand the effects of bioturbation on the movement of phytoliths in soils and sediments. Devos et al. (2009) examine phytoliths in thin-section and extractions to understand the origin and effects of bioturbation on the interpretation of the phytolith assemblages in 'Dark Earth' to identify intrusive morphotypes and different vegetation cover or land-use, whereas Gardner (2019) highlights the effects of increased porosity and the fragility of the sediment on their translocation.

Soil micromorphological analysis was conducted first to understand the sediments in the profile from Beckery, which appeared fairly homogenous in the field, and to identify areas of the profile to target for the extraction of microfossils. The micromorphological results revealed a range of bioturbation features and identified a variety of inclusions that suggested that livestock may have been penned in this building, specifically aggregates of 'organic-rich' sediment, coprolite fragments, intestinal parasite eggs, spores of potentially coprophilous fungi, and phytoliths. Subsequently, extractions of parasite eggs, dung fungal spores and phytoliths were conducted to provide further clarification about the microfossil identifications in thin-section and more detail about the range of livestock that was kept.

The identification of animal waste in thin-section is dependent on the type of animal (omnivore, carnivore, large herbivore, small herbivore, and variations within these categories), their diet, and the taphonomic factors that affect the preservation of the faecal remains within archaeological sediments (Canti 1999; van Geel and Aptroot 2006; Brönniman et al. 2017; Pümpin et al. 2017; Shahack-Gross 2017; Macphail and Goldberg 2018). Consequently, the identification of waste can be quite context specific, as palaeofaecal proxies can be affected by chemical and physical alterations as a consequence of the depositional environment (Macphail and Goldberg 2018), particularly in temperate climates, which is an important consideration for the profile at Beckery. 
Geoarchaelogical studies that examine the development of monastic and ecclesiatic sites in the UK are uncommon and limited to Lyminge, Kent, which investigated pre-Christian sunken-feature buildings and a waterlogged profile in the area of a stream close to the Great Hall complex in the Royal Settlement (Maslin 2015, 2018). In our innovative approach we investigate a bioturbated dryland context using soil micromorphology, combined with extraction protocols for phytolith, fungal spore and intestinal parasite egg analysis, including the morphometric examination of eggs. Extractions of non-pollen palynomorphs are rarely combined with micromorphological and phytolith analysis (eg. Banerjea et al. 2020; Maslin 2018); moreover, we focussed on a rare case of a nonwaterlogged animal enclosure from medieval northern Europe.

\section{Materials and Methods}

\section{Study site and stratigraphic sequence}

Beckery is a small ridge of Blue Lias (a sequence of limestone and shale layers) a short distance west of Glastonbury in Somerset (ST484383, Fig.1). The ridge is an island of solid geology, surrounded by floodplain deposits. In 2016 a geophysical survey on the site identified the presence of another stone building to the north of the chapel (Geoflow 2016 and Fig. 2). Excavation that year targeted that building as well as re-investigating the chapel area and an enclosing ditch.

Trench 2 was located to straddle the long axis of the building (Fig. 3). There was a sequence of three layers (54, 47 and 10 on fig.3) within the building, which are the subject of this detailed study, overlying a natural clay. No distinct floors were identifiable, but the chronological framework for the interior deposits is somewhat vague. It suggests that the interior deposits formed over a period of 200-400 years in the medieval period and ceased forming a short while before the dissolution of the Glastonbury Abbey estate in 1539. The ceramic chronology is as follows: Context 54, 950-1150; the youngest pottery from layer 47 is mid to late 12 th century; no pottery from layer 10 dates beyond the 13th to 15th centuries. Sealing both the internal deposits and the medieval layers to the south of the building, was a c. $80 \mathrm{~mm}$ deep layer of dark grey brown loam (1) containing numerous Lias stone fragments and broken roofing stone, which is dated by pottery to the 18th century.

The dates outside of the building show a similar chronology. The fill of the earliest feature produced an animal bone date of 991-1055 cal AD (50.8\%) or 1077-1154 cal AD (44.6\%) (SUERC-74420 984+/$29 \mathrm{BP}$ ). Two layers outside of the building along the southern wall line contained pottery of late Saxon/early Norman date (950-1150 AD). Overlying this was a dark grey-brown clay (12) that contained rubble, probably from the collapse of the building (large and small lias stones, including some roofing stone with nail holes), with ceramic dates up to 1550 AD date.

\section{Soil micromorphology}

Six thin-sections, $11.5 \times 7.5 \mathrm{~cm}$, were prepared from sub-samples that were collected from Monolith 6 (Fig. 4). The procedure followed the University of Reading standard protocol for thin section preparation. The samples were oven-dried to remove all moisture and then impregnated with epoxy resin while under vacuum. The impregnated samples were then left overnight so that the resin can 
enter all of the pores. The samples were then placed in an oven to dry for 18 hours at $70^{\circ} \mathrm{C}$ before they were clamped and cut to create a $1 \mathrm{~cm}$ slice through the sample. The surface of the $1 \mathrm{~cm}$ slice was flattened and polished by grinding on the Brot. The prepared surface of the $1 \mathrm{~cm}$ slice was then mounted onto a frosted slide and left to cure. This is followed by cutting off the excess sample, so the sample was ground down to a thickness of $1-2 \mathrm{~mm}$. The mounted sample was ground down to approximately $100 \mu \mathrm{m}$ in thickness using the Brot. The $100 \mu \mathrm{m}$ section was finally lapped on a Logitech LP30 precision lapping machine to the standard geological thickness of $30 \mu \mathrm{m}$.

Micromorphological investigation was carried out using a Leica DMLP polarising microscope at magnifications of 40x - 630x under Plane Polarised Light (PPL), Crossed Polarised Light (XPL), and where appropriate Oblique Incident Light (OIL). Thin-section description was conducted using the identification and quantification criteria set out by Bullock et al. (1985) and Stoops (2003) with reference to Mackenzie and Adams (1994) and Mackenzie and Guilford (1980) for rock and mineral identification, Nicosia and Stoops (2017) for the identification of inclusions, and Stoops et al. (2018) for further identification of post-depositional features and processes. Photomicrographs were taken using a Leica camera attached to the Leica DMLP microscope.

\section{Non-pollen palynomorphs (NPPs)}

Sub-sampling for NPPs targeted locations (Fig. 4) within the units identified in the micromorphological analysis, in which the effects of bioturbation and frequencies of dung and coprolite components could be co-investigated to examine taphonomy and the origin of parasite eggs and microfossils. One $\mathrm{cm}^{3}$ of sediment was sub-sampled and a known quantity of Lycopodium spores was added to enable calculation of concentrations. The material was sieved through 200 and $5 \mu \mathrm{m}$ meshes, prior to heavy liquid separation (sodium polytungstate, $2.0 \mathrm{~g} / \mathrm{mL}$ ), acetolysis (according to Faegri et al. 1989) and mounting of the residue in liquid glycerol. A second series of samples was prepared avoiding any treatment, apart from sieving through the same meshes. Light microscopy analysis was carried out at $x 400$ and $x 600$ magnifications using an Olympus $\mathrm{CH}-2$ compound microscope. Identifications were made following published keys (e.g. van Geel et al. 2003; van Geel and Aptroot 2006; Cuomo et al. 2009; Florenzano et al. 2012) and using reference slides from personal collections.

\section{Phytoliths}

Phytolith samples, collected from the same locations as the samples for NPP extractions (Fig. 4), were processed as follows using a protocol developed from Jenkins and Rosen (2007), in consultation with Hayley McParland, Historic England, to increase the sample size to $10 \mathrm{gm}$ to deal with the issues of sufficient clay removal in British sediments, which is an ongoing research question. Calcium carbonates were dissolved using a dilution of $10 \%$ hydrochloric acid. Sodium hexametaphosphate was added, agitated with a vortex mixer, then the samples were placed in a sonic bath for 3 minutes before clay was removed using a settling procedure. Organic matter was removed using a muffle furnace set at $550^{\circ} \mathrm{C}$. Phytoliths were then separated from the remaining material using density separation with sodium polytungstate calibrated to a specific gravity of 2.3 $\mathrm{g} / \mathrm{cm}^{3}$ and centrifuged for 8 minutes at $1000 \mathrm{rpm}$ with brake removed. Phytoliths were mounted onto slides using the mounting agent Entellan new. Microscope slides were assessed using a Leica 
DMLP polarising microscope using $x 400$ magnification. Analysis consisted of counting the slide until a minimum of 300 phytolith remains were recorded. Phytolith identifications were made with reference to Madella et al. (2005) and Piperno (2006).

\section{Description of the microstragraphic sequence}

The micromorphological data are provided in full in Supplementary tables 1-3: sediment descriptions for each deposit are recorded in Supp. table 1; the frequency and types of inclusions within these deposits are recorded in Supp. table 2; and the abundance of post-depositional alterations and pedofeatures within the deposits is recorded in Supp. table 3. These data are summarised in Table 1.

\section{Formation processes}

The sequence within Monolith 6 has been substantially reworked by earthworm and mite activity (Fig. 5), which is discussed further below, causing mixing of materials resulting in a similar sediment colour between Units 10 and 47 (Table 1): yellowish brown, greyish brown, dark brown in PPL; yellowish brown, dark orangey brown in XPL. All units are unsorted, have similar fine material comprising mineral and other microfossils, a similar groundmass, embedded and coated related distribution, and inclusions are unoriented, unrelated, random and unreferred indicative of haphazard processes, most probably as a result of earthworm activity. Phytoliths are disarticulated and occur in the earthworm channels, which indicates their movement through the profile. Dark brown sediment aggregates, which are sometimes optically isotropic indicating an organic composition, may represent aggregates of compressed dung and sediment from occupation within an animal pen, which has subsequently been reworked forming these sub-angular blocky peds (Fig. 5). As well as showing the movement of clay and mineral material, the groundmass is also crystallitic showing a calcitic origin of the sediment, which probably derives from the underlying surface geology ( $C$ horizon) above siltstone and limestone.

However, there are subtle differences in particle size (Table 1) between Units 10, 47 and 54, and in the types and frequencies of inclusions. The particle size becomes coarser towards the top of the sequence: Unit 10 is a sandy clay loam/sandy clay; Unit 47 is a sandy clay; and Unit 54 is a clay loam.

\section{Inclusions in thin-section}

The range and abundance of geological inclusions is consistent throughout the sequence (Supp. table 2). There are some differences in the types and abundances of inclusions throughout the profile, particularly between Units 10 and 47, and those within Unit 54 have most probably been reworked into the deposit from the overlying units.

There are some similarities between the units and slides (Table 1). Fungal spores (Figs. $6 \&$ 7) occur throughout, 5\%, and could represent coprophilous types, such as Sordaria (Fig. 6A), Unit 47, slide 6.4, and a possible Tilletia type (Fig. 7B), Unit 10, Slide 6.3. The spore types are identified more precisely by direct extraction from the sediment (see below). Also, small fragments of coprolite, possibly omnivore (Brönniman et al. 2017; Macphail and Goldberg 2018) occur largely throughout the sequence, $5 \%$; however, the main concentration of coprolite fragments, $10 \%$, occurs in Unit 10 , Slide 6.3. 
Sediment aggregates that formed from sub-angular blocky peds of dark brown, organic sediment (Fig. $5 A \& B$ ), non-burnt bone fragments, dung, charred wood, charred plant remains, and phytoliths occur throughout the sequence, but with some noticeable differences in abundances (Table 1). Sediment aggregates are most abundant in Unit 47, particularly at the base of this unit in slide 6.6, where they form $20 \%$ of the total inclusions, and at the top of the sequence in Unit 10, slide 6.1, where they form $10 \%$ of the total inclusions; a pollen grain, possibly from Plantago lanceolata, was also identified in this horizon. Phytoliths also occur most abundantly in Unit 47, 30-40\%, and $20 \%$ in Unit 10, and mainly represent taxa from monocotyledon plants such as elongate smooth, elongate sinuate, rondels, papillae, and trichome hair cells (Fig. 8). Fragments of dung and bone also occur most abundantly in Unit 47, particularly in the lower part of the unit in Slides 6.5 and 6.6. Parasite eggs that bear a strong resemblance to Ascaris (roundworm) type (Pilcher et al. 2014; Pümpin et al. 2017) were only identified in Unit 47 and are most abundant, 10\%, in slides 6.5 and 6.6 (Fig. 9), and are examined further by an extraction from the sediment.

Pottery fragments, $10 \%$, only occur in slide 6.3 in both Units 10 and 47 (Table 1), which may result from mixing at the boundary between these two units.

\section{Post-depositional alterations}

The sequence has been substantially affected by weathering, decay, and bioturbation processes (Supp. table 3). Both impregnative and depletion redoximorphic pedofeatures occur evident by the stippled speckled and dotted b-fabrics (Table 1). Their formation arises from the neoformation of iron and manganese nodules, and from silty clay/clay coatings that are also impregnated with Fe. These features can result from wet/dry cycles or fluctuations in the water table (Vepraskas et al. 2018). The formation of authigenic phosphate nodules and vivianite (Table 1) is commonly found in deposits containing herbivore and omnivore waste (Macphail and Goldberg 2018). The translocation of clay and silty clay particles is influenced by factors related to water flow, chemical conditions, energy, and gravity. Movement can occur under any kind of climate, although temperate environments provide the best evidence (Courty et al. 1989; Kühn et al. 2018). Dusty clay coatings form by the rotation of the sediment under damp conditions (Courty et al. 1989), which may result from trampling (by animals and people), and/or reworking of the sediment by earthworms, particularly as the fine material contains disarticulated phytoliths. The dark colour of dusty clay coatings is mainly caused by finely dispersed organic matter (Kühn et al. 2018). Darkening in colour, known as organic staining (Fig. 5A), is observed in thin-section from the decomposition of organic matter (Courty et al. 1989).

Bioturbation by earthworm and mite activity is prolific and evident from channels and chambers in the microstructure (Table 1) and excremental pedofeatures from Lumbricus terrestris (Canti 2007; 2017) and smooth ellipsoidal organo-mineral excrements from mites, which are found in association with decaying organic material (Kooistra and Pulleman 2018: 457-458) (Table 1; Fig. 5). Bioturbation has resulted in the disarticulation of grass phytoliths, which occur in the earthworm channels, indicating their movement through the profile, and the formation of sub-angular blocky peds of dark brown, organic sediment (Fig. 5A \& B). Therefore, it must be considered that other microfossils may have also been moved throughout the profile. 
A simple bioturbation index is applied to the microstratigraphic units in order to compare the levels of disturbance within the profile with the assemblages of extracted microfossils and is as follows: $\mathrm{L}$ (low), 20-30\%; $\mathrm{M}$ (medium), 30-40\%; $\mathrm{H}$ (high) $40-50 \%$. The percentages in this index are the sum of abundance percentages for all bioturbation features for each microstratigraphic unit, based on a visual estimate expressed as a percentage of the field of view as per Bullock et al. (1985): channels, chambers, excremental pedofeatures from earthworms and mites, and mesofaunal casts. Bullock et al. (1985) state that bioturbation $>25 \%$ is very abundant. Bioturbation in this profile is very abundant throughout and the index is used only for the purpose of comparison of microstratigraphic units within this profile.

\section{Extracted microfossils}

\section{Non-pollen palynomorphs}

Three types of eggs occur in the deposit. In treated and untreated samples, elongated elliptic eggs with two polar plugs belong to Trichuris sp. (whipworm) (Fig. 10,B-C). In the untreated samples only, a number of round/elliptical eggs with a ribbed coating belong to the genus Ascaris (large roundworm) (Fig. 10,A). In treated samples, a distinctive elliptic egg showing a wide aperture on one side (after the loss of the operculum) is likely to represent eggs of the genus Dicrocoelium, the lancet liver fluke.

A clear prevalence of parasite eggs of the genus Trichuris was evident, following the examination of the microscope slides prepared from acetolysed samples. This seemed to contrast with several Ascaris eggs observed in thin section, so that further slides were prepared, this time only using untreated sediment. This point has methodological implications for palaeoparasitological studies, so we decided to report the data from both, acetolysed and non-acetolysed samples (Fig. 11,A-B).

Overall, a great amount of eggs of intestinal parasites were recovered. The concentrations ranged from 0 (6.1-10) to c. 650 (6.6-47/54) eggs per $\mathrm{cm}^{3}$ of sediment in treated samples and from 0 (6.3$47)$ to c. 5900 (6.6-47/54) eggs in untreated samples. Against our expectations, Trichuris was present in two acetolysed samples (6.3-47 and 6.4-47) and absent in the corresponding untreated samples. However, Trichuris eggs subjected to acetolysis showed a pale appearance due to thinning of the walls (Fig. 10,C). Up to c. 100 dung fungal spores occurred (6.3-47). Aquatic protozoans (Arcella sp.) were also recovered in low amounts (6.6-47/54).

\section{Phytoliths}

The phytolith assemblages from all samples are broadly similar in both phytolith morphotypes and their abundances, with some subtle variations between stratigraphic Units 10 and 47, and in the assemblage from the lowest sample in the profile, which was collected at the boundary with Unit 54 below (Fig. 12). The assemblages from Unit $10(6.1 / 10$ and 6.3/10) contain greater abundances of elongate smooth morphotypes than those assemblages from Unit $47(6.4 / 47,6.5 / 47,6.6 / 47)$ with a 
slightly greater abundance of phytolith from dicotlyedon plants, sedges and saddles in Unit 47 than in Unit 10.

All of the assemblages are dominated by long cell phytolith from monocoytledon plants, which comprise mainly those morphotypes from the leaves and stems of grasses (elongate smooth, 30 $50 \%$, elongate sinuate, $<10 \%$, elongate rod, $5-10 \%$, rondel, $<10 \%$, crenate, $<5 \%$ ), with low abundances of morphotypes from the husk (elongate dendritic, $<5 \%$, papillae, $<5 \%$ ). Short cell morphotypes occur in low abundances and include bilobes and saddles, which are Poaceae/ Panicoidae forms and include wetland grasses. Diatoms and sponge spicules were also observed in extracted phytolith samples. Sedge phytoliths also occur, most abundantly, 5-10\%, in 6.6/47 and are not present in 6.1/10.

In terms of preservation there are some observable differences between the samples. In sample $6.1 / 10$ the phytoliths are often broken but in large pieces. In 6.3/10 the phytoliths were more corroded due to alkalinity (Piperno 2006), with 6.4/47 having less weathering and less detrital/background material. In 6.5/47 there was an abundance of fragments too small to identify but the sample contained the highest abundance of phytolith material. Finally, sample 6.6/47 has the best preservation, with a high concentration of whole phytoliths but with the most mineral (quartz) material obscuring the phytoliths.

\section{Discussion}

\section{The effects of bioturbation}

Phytolith data can provide a measure of the extent of sediment mixing (Grave and Kealhofer 1999), and in the case of Beckery, a record of plant materials that were present in the building. The phytolith record, when examined in combination with the soil micromorphological data, shows a predominance of Pooideae grasses that would suggest that hay was brought into the building as animal bedding and fodder. In addition to this, the presence of phytoliths from wetland plants (Panicoideae) could infer the use of peat as animal bedding when the building was first used as a stable.

The differences between the phytolith assemblages in each sample are subtle and in general they are fairly homogeneous, which could arise from the movement of organic material and phytoliths by mesofaunal activity. Soil micromorphological analysis of the profile shows bioturbation features throughout, arising from earthworm activity, Lumbricus terrestris, throughout, and mite activity at the base of Unit 47. Bioturbation itself is difficult to date and this profile from Beckery Chapel suggests that there could have been several phases of bioturbation, which could be examined in the future with a radiocarbon study on the earthworm granules (Canti et al. 2015). The levels of disturbance features fluctuate throughout the profile, but the abundance of earthworm granules increases towards the surface (Table 2). For example, Unit 47, thin-section 6.4, shows the highest level of disturbance, with the lowest level directly below, and medium level directly above. This could suggest that some of the high level of disturbance is historic and relates to a period when the unit was an exposed surface horizon. There is less degradation of phytoliths in this unit in 
comparison with those above (Table 2), which might relate to a more neutral surface environment. Unit 10 above was buried under collapsed structural material. An increased number of small fragments in the extracted phytolith assemblage in 6.5/47 (Table 2) could suggest that these phytoliths are infiltrations from upper layers (Devos et al. 2009), where they have translocated in void spaces (Gardner 2019). The unit at the base of the profile, 6.6/47, at the interface with the substrate, Unit 54, has the best preservation of extracted phytoliths and the highest concentration of complete/unbroken phytoliths. The higher levels of bioturbation in this unit could relate more to the mite activity associated with decaying organic matter as earthworm granules occur in low abundances, $<5 \%$.

The subtle differences that are observed in the phytolith record (Fig. 12) and in comparison with the bioturbation interpretation (Table 2) are echoed in the mycological and palaeoparasitological records (Fig. 11), with assemblages which are probably more in situ towards the base of the profile in 6.5/47 and 6.6/47, and perhaps a more diffuse situation towards the top of the profile. Interestingly, coprophilous fungal spores (Cercophora type and Sphaerodes fimicola) are most abundant in 6.3/10. This may be an effect of Cercophora and Sphaerodes growth and spore dispersal on top of Unit 47, which resulted in the spores enclosed at the bottom of 6.3/10 (the boundary between the two units is not sharp). This could suggest a period of disuse, which left the surface undisturbed allowing fungal sporulation, before the gradual end of this structure (Morandi 2018b, 2020).

The bioturbation effects in this profile through a livestock enclosure are consistent with the processes observed experimentally in an un-roofed space at Lejre, Denmark (Banerjea et al. 2015). Here a building that had previously been used for bone-working activities was re-used as an animal enclosure. The goats destroyed the roof on one side of the structure. The stratigraphic unit on the floor of the structure, which had formed from repeated depositions of dung, was completely reworked on the un-roofed side of the building as a result of bioturbation processes (Banerjea et al. 2015). Consequently, the deposit in the un-roofed side now formed a soil that supported vegetation, and bone fragments had been transported upwards by mesofauna from the stone-cobbled surface below into the newly formed soil. Herbivore coprolites had been completely broken down and their fragments had a haphazard arrangement where they were unoriented and randomly distributed within the soil unit, in contrast with the strongly oriented coprolites in the roofed side that were aligned parallel with the floor. At Beckery, we also observe coprolites (herbivore and omnivore) that have been completely broken down and their fragments have a haphazard arrangement (unoriented and randomly distributed).

\section{The evidence for animal husbandry}

This sequence has been extensively reworked by earthworms and mites as attested by the results of the soil micromorphological analysis. With this caveat, the microfossil analysis, augmented by soil micromorphology has identified several episodes in the life-cycle of this building where livestock were present. The evidence for animal excreta on the site is provided by a range of fungi growing on herbivore dung, whose spores are dispersed over a short distance (Fig. 11,A), such as Arnium, Sordaria, Podospora, Cercophora (van Geel et al. 2003), Sphaerodes fimicola (Morandi 2020) and Melanosporaceae (Morandi and Branch 2018). Dung from sheep/goat and cattle was the most likely 
substrate for these fungi, although also horse, fallow deer, fowl and rabbit faeces can be easily colonised by coprophilous taxa (Richardson 1972, 2001). Organisms typical of shallow pools and humid soils (Arcella sp.; Charman et al. 2000) were also recovered.

The livestock present during each of these episodes may also vary. Unit 47 seems to represent a period where this area was used to keep animals, with the main concentration of animal waste toward the base of the sequence in micromorphological slides 6.5 and 6.6, with 6.6 being the basal slide (Table 2). Micromorphology and NPP data from 6.6 show that the main period when livestock were housed in this building occurs at the beginning of its life-cycle at the boundary between Units 47 and the geology below, Unit 54 (Fig. 4). Fragments of omnivore coprolite, 5\%, amorphous herbivore dung, $10 \%$, occur in thin section, extracted parasite eggs are most abundant in sample 6.6/47 (Fig. 11), and Sordaria coprophilous spores are also present attesting to the presence of herbivore dung in close proximity. This sample also contains the greatest abundances of parasite eggs (Ascaris, Trichuris, Dicrocoelium) (Fig. 11). No calcareous faecal spherulites were observed in thin-section, despite the limestone-based Blue Lias substrate and occurrence of calcitic earthworm granules, which would support alkaline conditions. The occurrence of alkalinity is evidenced by the corrosion of phytoliths, particularly in 6.4/47 (Table 2). It should be noted that phytoliths degrade and disappear above pH 9 (Piperno 2006), spherulites below pH 7.7 (Canti 1999), and below pH 7.0 rapid dissolution of earthworm granules can be expected (Canti 2007). Occupation deposits have complex depositional histories and can include a wide range of materials, which, as experimental research has shown, can result in highly localised chemical alterations (Banerjea et al. 2015). Redoximorphic pedofeatures (Table 1 ) are observed in the Beckery profile, which could have formed as a result of water percolation arising from the failing roof that subsequently collapsed, which may explain the absence of spherulites. As demonstrated in an experimental livestock enclosure at Lejre, weathering effects on a dung deposit resulting from a failing roof can lead to complete dissolution of faecal spherulites (Banerjea et al. 2015), an observation also made on open-air pastoral sites (Brochier et al. 1992). Although faecal spherulites tend to be abundant within herbivore dung in neutral to alkaline conditions, these calcium carbonate particles do not always form, due to biological and environmental variables which are still to be fully understood (Canti 1999).

Micromorphological studies have occasionally considered parasite eggs (eg. Macphail et al. 2008; Pichler et al. 2014). However, they have been rarely studied both in thin section and as extracted microfossils from the same site (e.g. Arbon Bleiche 3: Akeret and Rentzel 2001; Le Bailly et al. 2003). The combined use of these methods is needed for a comprehensive investigation: extraction is fundamental to better observe the three-dimensional shape and morphological features of the eggs, allowing accurate identifications, whereas micromorphology enables the observation of the microdepositional context embedding the microfossils (Pümpin et al. 2017). In the research from Beckery, the identification of Ascaris in micromorphological thin-sections and their absence in the initial extractions using acetolysis prompted further examination of the raw sediment, which then identified Ascaris eggs; this phenomenon was also observed in previous research from Elbląg castle, Poland (Banerjea et al. 2020).

Palaeoparasitological results indicate that the most significant considerations for the implications for animal husbandry on the site revolve around the size of Trichuris eggs, most abundant in the acetolysed samples. Fig. 13 shows that the microfossils clustered within two size classes, 55-65 $\mu \mathrm{m}$ 
and 70-90 $\mu \mathrm{m}$. Eggs of this genus displaying a length between c. 50 and $65 \mu \mathrm{m}$ are characteristic of whipworm species affecting humans and pigs ( $T$. suis, T. trichiura), whereas larger eggs (c. 70-80 $\mu \mathrm{m}$ ) are typical of cattle, sheep, goat and other wild animals (e.g. T. ovis, T. discolor, T. vulpis) (Beer 1976; Thienpoint et al. 2003; Dark 2004). It is then plausible that after the initial coexistence of suids and bovids (6.6-47-54), changes in the main animals kept in the area occurred, as suggested by the variation between short (6.5-47), long (6.4-47) and again short eggs (6.3-10), perhaps indicating an alternating predominance of suids and bovids within the building. A further explanation might consider the possibility of particle size sorting by soil fauna, resulting in eggs of similar length being grouped together. However, it seems very unlikely that a difference of only c. 20-30 $\mu \mathrm{m}$ can cause differential sorting of the microfossils. There are subtle differences in the presence of faecal remains in samples 6.3/10 and 6.4/47 (Fig. 4), which may further support these changes (Table 2): an increase in the abundance of omnivore coprolites, $10 \%$, in thin section in slide 6.3 , whilst no omnivore coprolites were observed in slide 6.4.

Sediment aggregates that formed from sub-angular blocky peds of dark brown, organic sediment are most abundant in Unit 47, particularly at the base of this unit in slide 6.6 , where they form $20 \%$ of the total inclusions (Table 2). There are two explanations for the origin and formation of these peds. The first is that these peds represent re-worked horizons of 'stabling crusts', which form as a result of animal trampling and inputs into the soil of organic matter-rich dung and liquid waste. This process has been observed experimentally in a non-waterlogged context (Banerjea et al. 2015), and archaeologically in waterlogged contexts (Banerjea et al. 2020; Brönnimann et al. 2017). The second is that they represent fragments of peat that was brought into the building and used as animal bedding. The latter is not implausible and could be supported by the extracted microfossils of wetland origin corresponding with slide 6.6, Unit 47: a slightly greater abundance of phytoliths from dicotyledon plants and saddle morphotypes, which can be characteristic of wetland grasses, a noticeable increase in sedge phytoliths, diatoms, sponge spicules, and organisms typical of shallow pools and humid soils (Arcella sp.; Charman et al. 2000) were also recovered. Mite activity, identified by organo-mineral excrements (Fig. 5), was identified using micromorphology in Unit 47, and may result from mites being attracted to the decaying organic material in this unit; soil mites are an important part of the decomposition of this material. Peat is reportedly a good material to use in animal stables as it combines well with ammonia and does not lead to fungal problems that can be experienced with woodchip and straw (Lesté-Lasserre 2016; Saastamoinen et al. 2015; Sellers 2016). The extraction of Brue valley peat by Glastonbury Abbey is first documented in the early 13th century (Williams 1970, 29).

The palaeoparasitological results are in agreement with the scenario reconstructed through the study of the animal bone assemblage, where the by far prevailing families consist of bovids kept on site for wool, traction and milk (sheep/goat and cattle, compatible with longer Trichuris eggs) and suids exploited for lard and meat production (pig, compatible with shorter Trichuris eggs) (Higbee 2017). The importance of sheep-farming for wool making in Medieval England has been highlighted by previous studies (Stone 2003), with landowners managing extremely large flocks during the 1314th century (Page 2003). Occasionally, monasteries were also involved in the leasing of specimens (Stone 2003; McDonnel 1988). Unfortunately, the genus Ascaris (6.1-10) does not produce eggs morphologically and dimensionally diagnostic enough to infer infection of a particular animal family. 
The infection of animal intestine by whipworms and roundworms is common in traditional farming before the advent of pesticides, but usually this does not have a major impact on animal health. The symptoms associated with intestinal parasites in mammals are weight loss, anemia and cirrhosis (Cuomo et al. 2009; Morandi 2018a).

\section{The effects of extraction techniques on parasite egg assemblages}

On the methodological side, this sequence provided a textbook example of differential parasite egg preservation after acetolysis (sensu Faegri et al. 1989, i.e. three minutes in boiling water). This procedure was necessary to remove cytoplasm and facilitate the identification of fungal spores. In spite of the chemical treatment, a number of Trichuris eggs and sporadic Dicrocoelium eggs were observed (fig. 11,A). To assess the occurrence of selective destruction caused by acetolysis, a further series of samples was prepared avoiding any treatment. The examination of untreated samples revealed that the prevailing eggs in the deposit belonged in fact to Ascaris sp. (fig. 11,B). A greater resilience to acetolysis by eggs of Trichuris relative to eggs of Ascaris was reported by Herrmann (1986) and Reinhard et al. (1986), although in some sites Ascaris also survived acetolysis (Reinhard et al. 1986 and Florenzano et al. 2012, both with extensive bibliography). These authors put forward an explanation based on local sediment chemistry, suggesting that high cellulose content in the soil may neutralise the acetolysis solution, resulting in the preservation of Ascaris eggs (Reinhard et al. 1986).

Such a difference between our treated and untreated egg assemblages is an important observation, as the selective destruction of Ascaris has not been frequently addressed in the literature after the pioneering studies in the 1980s (a notable exception is Florenzano et al. 2012, where a light version of acetolysis avoiding boiling is recommended to overcome the issue). Therefore, to overlook this issue might lead to misleading interpretations of past faunal abundance and composition.

\section{Conclusions}

Examples of animal enclosures and their interpretations in Shahack-Gross (2017) largely derive from Mediterranean or African examples. This is a rare geoarchaeological example of an animal enclosure from a non-waterlogged context in a temperate environment in northern Europe. The structure seems to have been used solely as a livestock enclosure during its life-history. Towards the end of its life, it was used as a space to dump refuse, at a period when the roof was failing, prior to its collapse. The profile is extensively reworked by bioturbation, processes that were probably triggered by weathering resulting from the failing roof. A comparable experimental example from Lejre, Denmark, a temperate environment, shows that dung deposits can be completely reworked into a soil within 2.5 years of the roof failing (Banerjea et al. 2015).

The profile from Beckery provided great potential, through the application of a multi-proxy geoarchaeological approach, for understanding this area within an important early medieval ecclesiastical site despite the extensive reworking of the sediments. Soil micromorphology enabled the different types of bioturbation and post-depositional alterations and their effects on the sediments to be identified and untangled, which would not have been possible with conventional 
stratigraphic recording. Consequently, the analyses were able to identify the possible use of peat as bedding at the beginning of the life-history of the animal enclosure, and to demonstrate that this material and its associated microfossils are in situ.

Our palaeoparasitological results confirmed the resilience of Trichuris eggs relative to Ascaris eggs. Further, changes in the average size of eggs in different layers suggest an alternation between bovids and suids within the enclosure. The presence of herbivores is also highlighted by a range of dung fungal spores occurring throughout the profile.

Our results from this dryland context highlight the potential for future studies to integrate micromorphology, paleoparasitology and mycology as a suite of techniques to examine animal management, changes in husbandry practices, seasonality, and changes in diet arising from religious practices on ecclesiastical sites and landscapes. The integration of these approaches clearly demonstrates that these microfossils can survive well in a non-waterlogged profile, and they could be applied to archaeological sites more generally.

\section{References}

Akeret, Ö., \& Rentzel, P. 2001. Micromorphology and plant macrofossil analysis of cattle dung from the Neolithic lake shore settlement of Arbon Bleiche 3. Geoarchaeology: an International Journal, 16(6), 687-700.

Banerjea, R. Y., Badura, M., Brown, A., Morandi, L. F., Marcinkowski, M., Valk, H., Ismail-Meyer, K., Pluskowski, A. 2020. Feeding the Crusades: archaeobotany, animal husbandry and livestock alimentation on the Baltic frontier. Environmental Archaeology, 25 (2), 135-150.

Banerjea, R. Y., Bell, M. G., Matthews, W. and Brown, A. D. 2015. Applications of micromorphology to understanding activity areas and site formation processes in experimental hut floors. Archaeological and Anthropological Sciences, 7 (1). pp. 89-112

Beer, R.J. 1976. The relationship between Trichuris trichiura (Linnaeus 1758) of man and Trichuris suis (Schrank 1788) of the pig. Research in veterinary science, 20(1), 47-54.

Brochier, J. E., Villa, P., Giacomarra, M., \& Tagliacozzo, A. 1992. Shepherds and sediments: geoethnoarchaeology of pastoral sites. Journal of Anthropological Archaeology, 11, 47-102.

Borderie, Q., Y. Devos, C. Nicosia, C. Cammas, and R. I. Macphail. 2014. "Dark Earth in the Geoarchaeological Approach to Urban Contexts." In French Geoarchaeology in the 21th Century, 245-255. Paris: CNRS. 
Brönnimann, D., Ismail-Meyer, K., Rentzel, P., Égüez, N. 2017. Excrements of Herbivores. In C. Nicosia, G. Stoops (eds) Archaeological Soil and Sediment Micromorphology. Chichester, John Wiley \& Sons, pp. 55-66.

Bulleid. 1936. St Bridget's Chapel, Beckery, Proceedings of the Somerset Archaeology and Natural History, 82, 238-9

Bullock, P., Fedoroff, N., Jongerius, A., Stoops, G., Tursina, T. 1985. Handbook for thin section description. Wolverhampton: Waine Research.

Canti, M. G. 1999. The production and preservation of faecal spherulites: animals, environment and taphonomy. Journal of Archaeological Science, 26(3), 251-258.

Canti, M. G. 2003. Earthworm activity and archaeological stratigraphy: a review of products and processes. Journal of Archaeological Science, 30(2), 135-148.

Canti, M. G. 2007. Deposition and taphonomy of earthworm granules in relation to their interpretative potential in quaternary stratigraphy J. Quat. Sci., 22, 111-118

Canti, M. G. 2017. Biospheroids produced by earthworms. In C. Nicosia, G. Stoops (eds) Archaeological Soil and Sediment Micromorphology. Chichester, John Wiley \& Sons, pp. 47-49

Canti, M., Bronk-Ramsey, C., Hua, Q., \& Marshall, P. 2015. Chronometry of pedogenic and stratigraphic events from calcite produced by earthworms. Quaternary Geochronology, 28, 96-102.

Charman, D.J., Hendon, D., Woodland, W.A. 2000. The identification of testate amoebae (Protozoa: Rhizopoda) in peats. Quaternary Research Association.

Courty, M.A., Goldberg, P., Macphail, R. 1989. Soils and micromorphology in archaeology. Cambridge: Cambridge University Press.

Cuomo, M. J., Noel, L. B., White, D. B. 2009. Diagnosing medical parasites: a public health officers guide to assisting laboratory and medical officers. Randolph, TX: USAF Air Education and Training.

Dark, P., 2004. New evidence for the antiquity of the intestinal parasite Trichuris (whipworm) in Europe. Antiquity, 78(301), 676-681.

Darwin C. 1881. The formation of vegetable mould through the action of worms with observations on their habits. John Murray, London.

Devos, Y., Vrydaghs, L., Degreave, A., Fechner, K. 2009. An archaeopedological and phytolitarian study of the "Dark Earth" on the site of Rue de Dinant (Brussels, Belgium). Catena 78 (3), 270-284

Faegri, K., Kaland, P.E. and Krzywinski, K., 1989. Textbook of pollen analysis. Hoboken, NJ: John Wiley \& Sons. 
Florenzano, A., Mercuri, A. M., Pederzoli, A., Torri, P., Bosi, G., Olmi, L., Rinaldi, R., Bandini Mazzanti, M. 2012. The Significance of Intestinal Parasite Remains in Pollen Samples from Medieval Pits in the Piazza Garibaldi of Parma, Emilia Romagna, Northern Italy. Geoarchaeology, 27(1), 34-47.

Geoflow, 2016. Beckery Chapel Geophysical Survey April 2016. Report GF1047. Geoflow Ltd. Taunton.

Gardner, T. H. 2019. Assessing the contribution of integrated geoarchaeological approaches to understand the formation and function of burnt mounds: the example of Hoppenwood Bank, North Northumberland. Archaeology Journal 176, 51-83

Gilchrist, R. 2020. Sacred Heritage: Monastic Archaeology, Identities, Beliefs. Cambridge: Cambridge University Press.

Gilchrist, R., Green, C. 2015. Glastonbury Abbey: Archaeological Investigations 1904-79. London: Society of Antiquaries.

Grave, P., Kealhofer, L., 1999. Assessing Bioturbation in Archaeological Sediments using Soil Morphology and Phytolith Analysis. Journal of Archaeological Science 26 (10) 1239-1248

Higbee, L. 2017. Beckery Chapel : Animal Bone. Wessex Archaeology specialist report.

Herrmann, B. 1986. Parasitologische Untersuchung mittelalterlicher Kloaken. In: B. Herrmann (Ed.), Mensch und Umwelt im Mittelalter. Stuttgart: Deutsche Verlags-Anstalt, 160-169.

Jenkins, E. L., and A. M. Rosen. 2007. "The Phytoliths." In The Early Prehistory of Wadi Faynan, Southern Jordan: Archaeological Survey of Wadis Faynan, Ghuwayr and al-Bustan and Evaluation of the PrePottery Neolithic A Settlement of WF16, edited by B. Finlayson, and S. Mithen, 429-436. Oxford, England: Oxbow Books

Kooistra, M. J., Pulleman, M. M. 2018. Features related to faunal activity. In G. Stoops,, V. Marcelino, F. Mees, Interpretation of micromorphological features of soils and regoliths. Elsevier, Amsterdam, pp. 447-469

Kúhn, P., Aguilar, J., Miedema, R., Bronnikova, M. 2018. Textural pedofeatures and related horizons. In G. Stoops,, V. Marcelino, F. Mees, Interpretation of micromorphological features of soils and regoliths. Elsevier, Amsterdam, pp. 377-423

Le Bailly, M., Leuzinger, U., \& Bouchet, F. (2003). Dioctophymidae eggs in coprolites from neolithic site of Arbon-Bleiche 3 (Switzerland). Journal of Parasitology, 89(5), 1073-1077.

Lesté-Lasserre, C. 2016. Peat Gets Thumbs Up as Horse Bedding. The Horse https://thehorse.com/17024/peat-gets-thumbs-up-as-horse-bedding/ 
Mackenzie, W.S., Adams, A.E. 1994. A Colour Atlas of Rocks and Minerals in Thin Section. New York: John Wiley and Sons.

Mackenzie, W.S.,Guilford, C. 1980. Atlas of Rock Forming Minerals. Harlow: Longman Group Ltd.

Macphail, R. I. 1994. The reworking of urban stratigraphy by human and natural processes. In A. R. Hall \& H. K. Kenwood (eds) Urban-Rural Connexions: Perspectives from Environmental Archaeology. Oxford: Oxbow. pp 13-43.

Macphail, R. I., Goldberg, P. 2018. Archaeological Materials. In G. Stoops,, V. Marcelino, F. Mees, Interpretation of micromorphological features of soils and regoliths. Elsevier, Amsterdam, pp. 779819

Macphail, R. I., Haită, C., Bailey, D. W., Andreescu, R., \& Mirea, P. 2008. The soil micromorphology of enigmatic Early Neolithic pit-features at Măgura, southern Romania. Studii de preistorie, 5, 61-77.

Madella,M. Alexandre, A. Ball, T. 2005, International Code for Phytolith Nomenclature 1.0. Annals of Botany, 96 (2), 253 - 260.

Maslin S. P. 2015. The taphonomy and micromorphology of sunken-feature buildings from Lyminge, Kent: a comparative mixed-method analysis. Environmental Archaeology 20 (2), 202-220

Maslin, S. P. 2018. Anglo-Saxon economy and ecology by a downland stream. Environmental Archaeology 23 (2), 137-151

McDonnel, J. 1988. The role of transhumance in northern England. Northern History, 24(1), 1-17.

Morland, J. 1889. St Bridget's Chapel, Beckery. Proc. Somerset Archaeology and Nat. Hist. Soc. 35, 121-126.

Morandi, L. F. 2018a. Parasite ova and cysts. In: S. L. López Varela (ed.), The Encyclopedia of Archaeological Sciences, Wiley, DOI: 10.1002/9781119188230.saseas0442.

Morandi, L. F. 2020. An ethnoarchaeological case study of dung fungal spore and faecal spherulite taphonomy in a pastoral cave deposit. Environmental Archaeology, 25 (2), 198-207.

Morandi, L. F. 2018b. Non-pollen palynomorphs as an aid to the identification of ancient farming activities: an experimental and archaeological approach. Unpublished PhD dissertation, University of Reading.

Morandi, L. F. , Branch, N. P. 2018. Long-range versus short-range prehistoric pastoralism. Potential of palaeoecological proxies and a new record from western Emilia, northern Apennines, Italy. In: Pelisiak, A., Nowak, M. and Astaloş, C. (eds.), People and the Mountains. Current Approaches to the Archaeology of Mountainous Landscapes. Archaeopress, 47-60. 
Nicosia, C., Stoops, G. 2017. Archaeological Soil and Sediment Micromorphology. Chichester, John Wiley \& Sons

Page, M. 2003. The technology of medieval sheep farming: some evidence from Crawley, Hampshire, 1208-1349. The Agricultural History Review, 137-154.

Pichler, S. L., Pümpin, C., Brönnimann, D., \& Rentzel, P. (2014). Life in the proto-urban style: the identification of parasite eggs in micromorphological thin sections from the Basel-Gasfabrik Late Iron Age settlement, Switzerland. Journal of archaeological science, 43, 55-65.

Piperno, D. R. 2006. Phytoliths: A Comprehensive Guide for Archaeologists and Paleoecologists. AltaMira Press

Pümpin, C., Le Bailly, M., \& Pichler, S. (2017). Ova of intestinal parasites. In: Nicosia, C., \& Stoops, G. (Eds.), Archaeological soil and sediment micromorphology. John Wiley \& Sons, 91-97.

Rahtz, P. and Hirst, S. 1974. Beckery Chapel, Glastonbury 1967-8. Glastonbury Antiquarian Society. Glastonbury.

Reinhard, K. J., Confalonieri, U. E., Herrmann, B., Ferreira, L. F., de Araujo, A. J. 1986. Recovery of parasite remains from coprolites and latrines: aspects of paleoparasitological technique. Homo, 37(4), 217-239.

Richardson, M. J. 1972. Coprophilous ascomycetes on different dung types. Transactions of the, British Mycological Society, 58(1), 37-48.

Richardson, M. J. 2001. Diversity and occurrence of coprophilous fungi. Mycological Research, 105(4), 387-402.

Richter, R. 1952. Fluidal-Textur in Sediment-Gesteinen und über Sedifluktion überhaupt. Notizbl Hess Landesamtes Bodenforsch Wiesb 6: 67-81

Saastamoinen, M., Särkijärvi, S., Hyppä, S. 2015. Reducing Respiratory Health Risks to Horses and Workers: A Comparison of Two Stall Bedding Materials. Animals (Basel) 5 (4), 965-77

Schiffer, M. B. 1983. Toward the Identification of Formation Processes. American Antiquity 48 (4), 675-706

Shahack-Gross, R. 2017. Animal gathering enclosures. In C. Nicosia, G. Stoops (eds) Archaeological Soil and Sediment Micromorphology. Chichester, John Wiley \& Sons, pp. 265-280

Sellers, F. 2016. The Pros and Cons of Peat Moss Bedding for Your Horse. EQUIMED Horse Health Matters https://equimed.com/news/general/the-pros-and-cons-of-peat-moss-bedding-for-yourhorse 
Stiner, M. C., Kuhn, S. L., Surovell, T. A., Goldberg P., Meignen, L., Weiner, S., Bar-Yosef, O. 2001. Bone Preservation in Hayonim Cave (Israel): a macroscopic and mineralogical study. Journal of Archaeological Science, 23 (6), 643-659

Stone, D. 2003. The productivity and management of sheep in late medieval England. The Agricultural History Review, 1-22.

Stoops, G. 2003. Guidelines for Analysis and Description of Soil Thin Sections. Madison: Soil Science Society of America.

Stoops, G., Marcelino, V., Mees, F. 2018. Interpretation of micromorphological features of soils and regoliths. Elsevier, Amsterdam

Thienpont, D., Rochette, F. Vanparijs, O. F. J. 2003. Diagnosing Helminthiasis by Coprological Examination (First Edition 1979). Beerse: Janssen.

Thomas, G., Pluskowski, A., Gilchrist, R., Ruiz, G. G.-C., Andrén, A., Augenti, A., Astill, G., Staecker, J. and Valk, H. 2017. Religious transformations in the Middle Ages: towards a new archaeological agenda. Medieval Archaeology, 61 (2), 300-329

van Geel, B., \& Aptroot, A. 2006. Fossil ascomycetes in Quaternary deposits. Nova Hedwigia, 82(3-4), 313-329.

van Geel, B., J. Buurman, O. Brinkkemper, J. Schelvis, A. Aptroot, G. B. A. van Reenen, and T. Hakbijl. 2003. Environmental Reconstruction of a Roman Period Settlement Site in Uitgeest (The Netherlands), with special reference to coprophilous fungi." Journal of Archaeological Science 30, 873-883.

Vepraskas, M. J., Lindbo, D. L., Stolt, M. H. 2018. Redoximorphic features. In G. Stoops,, V. Marcelino, F. Mees, Interpretation of micromorphological features of soils and regoliths. Elsevier, Amsterdam, pp. $425-445$

Williams, M. 1970. The Draining of the Somerset Levels. Cambridge. Cambridge University Press.

\section{Figure Captions}

Figure 1 Maps showing A) the location of Glastonbury, UK, and B) the local area around Glastonbury with the location of the site at Beckery.

Figure 2 Plan showing the location of the trenches at the Beckery excavation in relation to the geophysical data. 
Figure 3 Plan (upper diagram) and profile (lower diagram) of Trench 2. The location of the monolith sample (see Figure 4) is marked on the profile.

Figure 4 Photograph of Monolith 6 in situ (left). The monolith being sub-sampled for micromorphological analysis with the locations of the microfossil samples marked with white rectangles (centre). The corresponding micromorphology thin-sections with stratigraphic units (right).

Figure 5 Pedofeatures from earthworm and mite activity: dark brown, organic, sub-angular blocky peds, Unit 47, Slide 6.6 in PPL (A) and XPL (B); Internal chamber formed of excreta by an earthworm in faunal void, Unit 10, Slide 6.3 (C) (Kooistra \& Pulleman 2018); Calcitic earthworm granule probably from Lumbricus terrestris, Unit 47, Slide 6.4 (D) (Canti 2007); Organo-mineral mite excrements in chamber voids, Unit 47, Slide 6.6 (E \& F) (Kooistra \& Pulleman 2018).

Figure 6 Possible sordaria spore, Unit 47, Slide 6.4 (A); Possible coprophilous fungal spores, Unit 47 , Slide 6.4 and 6.5 respectively (B \& C)

Figure 7 Unknown, possibly an ascocarp type, Unit 47, Slide 6.6 (A); Possible tilletia type, Unit 10, Slide 6.3 (B); Unknown microfossil/spore, Unit 47, Slide 6.4 (C).

Figure 8 Decayed plant remains with organic staining and rondel phytolith, PPL (A); Fine material containing phytoliths: dendritic, elongate smooth, and trichome hair, PPL (B). Both Unit 47, Slide 6.5 .

Figure 9 Parasite eggs in micromorphological thin-sections. Ascaris sp. parasite eggs from Unit 47, Slides 6.5 (A) and 6.6 (B, C, D). A \& D are cross-sectioned. B \& C are cut diagonally. C is situated within a phosphate-stained matrix with phytoliths.

Figure 10 Eggs of extracted parasitic helminths. A: Ascaris sp. (two eggs, non-acetolysed); B: Trichuris sp. (non-acetolysed); C: Trichuris sp. (centre, acetolysed). Scale bars $=\mathbf{2 0} \mu \mathrm{m}$.

Figure 11 Diagrams showing the concentration of microfossils per $\mathrm{cm}^{3}$ of sediment. A: parasite eggs and other microfossils from acetolysed samples; B: parasite eggs from non-acetolysed samples.

Figure 12 Diagram showing the proportions of phytolith morphotypes through the profile

Figure 13 Boxplots showing the size range of Trichuris sp. eggs. Elongated upper whiskers and outliers in samples 6.5-47 and 6.6-47 derive from the presence at the same time of species affecting cattle, dogs and wild animals (longer eggs) along with Trichuris suis (shorter eggs), as indicated by the bimodal distribution within these two samples. 
Table 1 Summary of descriptive sediment attributes, selected inclusions, and selected postdepositional alterations, Beckery Chapel, UK. The legends for the inclusions and post-depositional alterations follow Bullock et al. (1985). Inclusions: $* * * * * *$ Very dominant $>70 \%$; $* * * *$ Dominant 50-70\%; **** Common 30-50\%; *** Frequent 15-30\%; ** Few 5-15\%; * Very few <5\%. Post-

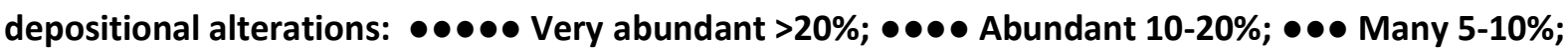
$\bullet \bullet$ Occasional 2-5\%; • Rare <2\%

Table 2 A summary of the integrated results of micromorphology, NPP and phytolith analyses. EX = extraction; TS $=$ thin section. Extracted phytoliths with abundances $>5 \%$ are tabulated. Key for the bioturbation index: $\mathrm{L}=$ low, $20-30 \%$; $M=$ medium, $30-40 \%$; $\mathrm{H}=$ high, $40-50 \%$. 